\title{
Dental Caries as an Archaeological Problem-Solving Tool: Reconstructing Subsistence Patterns in Late Prehistoric West- Central Tennessee
}

\author{
Maria Ostendorf Smith ${ }^{1 *}$ and Tracy K. Betsinger ${ }^{2}$ \\ ${ }^{1}$ Department of Sociology and Anthropology, Illinois State University \\ ${ }^{2}$ Department of Anthropology, SUNY Oneonta
}

Keywords: Mississippian, maize, dental caries, carious lesions, Tennessee

\begin{abstract}
The dentition from two Middle Mississippian period ( AD 1100-1350) site samples (Gray Farm [ AD 1100-1350], Link/Slayden [ AD 1100-1400]) from the Kentucky Lake Reservoir of westcentral Tennessee area are examined for caries prevalence by tooth type, lesion size, and crown-root location to assess whether a maize-intensive subsistence economy is evident. Given the paucity of local archaeological context, comparative caries prevalence and pattern operate as a critical archaeological problem-solving tool. The Middle Mississippian samples are compared to a Kentucky Lake Late Woodland period ( AD 400-900) horticulturist site sample (Hobbs) as well as three unequivocal maizeintensive agriculturalist site samples from the Late Mississippian period of East Tennessee ( AD 13001550). The caries patterns (tooth type, location, size) in the Gray Farm sample is consistently not statistically different from the maize-intensive samples; Link/Slayden is consistently statistically different and resembles the caries pattern and prevalence of the Hobbs sample. The adoption of maize as a primary cultigen in the Kentucky Lake Reservoir is evidently geographically variable. This may reflect local ecological contexts or differential socio-economic contacts with neighboring Mississippian economies. Or, more likely, it may reflect temporal differences in Mississippianization between the Kentucky Lake Reservoir sites.
\end{abstract}

Paleopathological data in sample-based bioarchaeological inquiry are a well-established adjunct to archaeological problem-solving (e.g., Buikstra and Beck, 2017; Larsen, 2015; Martin et al., 2013). Although the reconstruction of extinct cultures is largely the purview of archaeology, many archaeological contexts, such as mortuary sites and salvage projects, lack the associated material culture to address basic questions about subsistence, settlement pattern, and social organization. In these circumstances, bioarchaeological data can be an effective primary archaeological problem-solving tool (e.g., Armelagos, 2003; Larsen, 2015; Mosher et al., 2015; Smith et al., 2016; Stojanowski \& Duncan, 2015). Dental caries prevalence and severity can be particularly effective as a benchmark of agricultural intensification and the dietary primacy of particular fermentable carbohydrates (e.g., Caselitz, 1998; Karsten et al., 2015; Larsen, 1991, 2005; Lubell et al., 1994; Lukacs, 1992; Patterson, 1986; Šlaus et al., 2011; Temple \& Larsen, 2007; Turner, 1979). Carious lesions are the consequence of the demineralization of tooth enamel by the metabolic processes of certain oral bacteria (e.g., Streptococcus mutans) in the presence of refined carbohydrates. In the
Americas, the primary cariogenic carbohydrate of agricultural intensification (post AD 900 - Contact) is maize (Zea mays) (e.g., Simon, 2017; Smith, 2017; VanDerwarker et al., 2017), particularly the variant known as northern "flint corn" (Zea mays indentata) (Simon, 2017). It is commonly asserted that caries incidence rises dramatically with the adoption of maize (e.g., Emerson et al., 2005; Larsen, 1981; Powell, 1985; Watson, 2005). However, the increase is not simply a reflection of absolute carbohydrate consumption as other, likely synergistic factors (e.g., rate of attrition, hypoplastic defects, and malocclusion), affect individual vulnerability to cariogenesis. Complicating the subsistence inferences, documentation of caries prevalence across the late prehistoric site samples from the contiguous United States can be variable and uneven. Often this

\footnotetext{
*Correspondence to:

Maria Ostendorf Smith ${ }^{1}$

Department of Sociology and Anthropology

Illinois State University

Normal, Illinois 61790-4660

msmith@ilstu.edu
} 
reflects sample preservation, as dental data are differentially available: loose teeth, in situ presence, and antemortem (alveolar resorption) and postmortem (empty sockets) tooth loss. Recording can consist of the prevalence of carious individuals, the prevalence of carious teeth, prevalence of carious teeth by tooth class, and/or the application of caries correction factors. The result is often a lack of inter-site comparability. This can be interpretively problematic as the temporal transition to maizeintensive agriculture is ecologically, geographically, and socio-politically variable (Emerson et al., 2005; Hutchinson et al., 1998; Scarry, 1993; Wilson, 2017). The adoption of stable isotope analysis (i.e., $\mathrm{C}^{3} / \mathrm{C}^{4}$ ratios prevalence) allowed archaeologists to sidestep the shortcomings of osteological preservation and the quantitative methodology issues.

However, this option is not available for many preColumbian human osteological samples in the contiguous United States as destructive analysis is not permitted. ${ }^{1}$

The intensive adoption of maize as a primary cultigen across the eastern continental United States throughout the middle and lower Mississippi River Valley, the lower Ohio River Valley, and the Southeastern United States north of Florida cooccurs with the most recent pre-Columbian cultural horizon, the Mississippian Period ( AD 1000 1500) (Bense, 2016; King, 2017; VanDerwarker, 2017; Wilson, 2017). The horizon reflects the most complex sociopolitical organization north of Mesoamerica (Bense, 2016; Smith, 1990) and is archaeologically manifested by the presence of large aggregated village settlements, often palisaded, that were organized around a central plaza. The plaza, in turn, was flanked by one or more quadrilateral flat-topped mounds with variable functions (e.g., mortuary, domiciliary, temple) (Dalan, 1997; Kidder, 2004; King, 2001; King, 2017; Lewis et al., 1998). Some level of centralized authority (arguably chiefdom-level) is evident (Beck, 2003; Cobb, 2003; King, 2017; Pauketat, 2007). The Mississippian Period is also characterized by a complex iconography (i.e., the "Southeastern Ceremonial Complex" [SECC] or "Southeastern Ceremonial Exchange Network" [SCEN]) of sociopolitical as well as cosmological meaning (Knight, 2006;

Knight et al., 2001; Muller, 1989; Reilly and Garber, 2007). The apex of Mississippian culture occurred in the Middle period (CE 1200-1400) when the hallmarks of Mississippian culture are present throughout the middle and lower Mississippi River Valley, the lower Ohio River Valley, and the Southeastern United States north of Florida.
Plant domestication has a long trajectory in the pre-Columbian eastern US (e.g., Fritz, 1990; Scarry, 2008; Smith, 2006, 2011; Smith and Yarnell, 2009). Prior to the dedicated adoption of maize, cultigens consisted of a suite of native oily (e.g., sunflower and marsh elder) and starchy seed grasses (e.g., maygrass, knotweed, lamb's quarter, little barley) referred to as the Eastern Agricultural Complex (EAC) (Scarry, 2008; Smith, 2006; Smith and Yarnell, 2009). The transition from native grasses to maize cultivation was not temporally or geographically uniform and may have been influenced by ecological constraints or peripheral geographic location relative to the Mississippian cultural heartland (e.g., Fritz, 1990; Smith, 2011; 2017). Within this Mississippian culture area, regional polities occur that differed in social complexity and the adoption of Mississippian cultural elements. One of these variants, the Middle Cumberland Culture (MCC), is physiographically concentrated in the Nashville Basin of central Tennessee (Dowd, 2008; Ferguson, 1972; Moore et al., 2006; Smith, 1992) and extends from the Cumberland River drainages between the confluence of the Caney Fork and Cumberland Rivers in the east to the confluence of the Red and Cumberland Rivers in the west (Figure 1). It has been archaeologically observed that the Nashville Basin had a high population density in late prehistory and mirrored the Mississippian socioeconomic pattern of mound centers and agriculturalization (Beahm, 2013; Jolley, 1983). Maize cultivation, likely intensive, is evident in MCC sites (Beahm, 2013; Buikstra, et al., 1988; Crites, 1984).

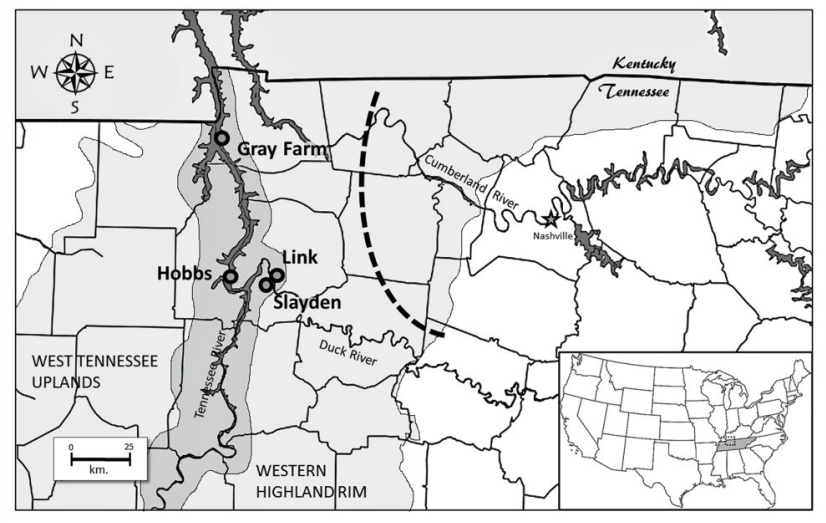

Figure 1. Map of west-central Tennessee identifying the location of the site samples in the Tennessee River Valley. The valley is flanked by two highland areas: the West Tennessee Uplands and the Western Highland Rim. The dashed line demarcates the western most extent of the middle Cumberland Culture. 
There are numerous Middle Mississippian sites in the Tennessee River valley west of the highland areas and beyond the western boundary of the MCC in, and adjacent to, what is now the Kentucky Lake Reservoir. Maize-intensive agriculture is ubiquitous in the Late Mississippian period ( AD 1350-1550) (Bense, 2016; King, 2017;

VanDerwarker, 2017; Wilson, 2017), but geographically variable in the Middle Mississippian period. Identifying the subsistence patterning is particularly important in the Kentucky Lake area because there are no Late Mississippian components for any site as the region was inexplicably abandoned by circa AD 1450 (Bass, 1985; Cobb and Butler, 1992; Williams, 1990). With little evaluated archaeological material culture from Kentucky Lake, the dental caries data from sites in this apparent cultural frontier provide critical insight into the dietary importance of maize.

\section{Materials and Methods}

The three Kentucky Lake Reservoir sites examined for caries prevalence and patterns are physiographically located in the Western Valley of the Lower Tennessee River, which is situated between two highland areas (see Figure 1). To the west, are the Western Tennessee Uplands and to the east, the Western Highland Rim of the Nashville Basin. The sites were excavated as salvage archaeological projects prior to the completion of the Kentucky Dam (Gilbertsville, Kentucky) (1938-1944). Two of the west-central Tennessee archaeological sites, Link (40HS6) and Slayden (40HS1), are located on river bluffs above the Duck River, a tributary of the Tennessee River, at the confluence of its tributary, the Buffalo River. The sites are within twenty kilometers of the confluence of the Duck River with the Tennessee River. They are argued to be the same settlement context and are thus evaluated together. Link/Slayden was a multi-mound Mississippian context dating to the Early-to-Middle Mississippian period ( AD 1100-1350) (Bass, 1985; Dye, 2002, 2003; Kuemin Drews, 2000; Lunn, 2013). The Link site is the source of the Duck River Cache, arguably the most spectacular collection of Native American stone work (i.e., circa four dozen stone maces, stone knives, stone daggers) recovered in the Eastern United States (Brehm, 1981; Dye, 2007). The Gray Farm site (40SW1) is a Middle Mississippian multi-mound site located on the eastern bank of the Tennessee River just north of the confluence of the Big Sandy River (Bass, 1985; Kuemin Drews, 2001). Temporally it appears to be as old as Link/ Slayden, but archaeological evidence (ceramics and domestic structure types) suggests it was occupied longer (Bass, 1985). It is approximately 50 air kilometers north of Link/Slayden. The third Kentucky Lake Reservoir site assessed for dental caries dates to the Late Woodland ( AD 500-900) period (Kuemin Drews, 2001). Hobbs (40HS44) is a mound mortuary context located downstream from Link/Slayden on the main channel of the Tennessee River (see Figure 1). Archaeologically it co-occurs with the cultivation of the native grasses of the Eastern Agricultural Complex (Smith and Yarnell, 2009).

The permanent dentition of adult burials from the Kentucky Lake site samples was canvassed for the presence of carious lesions. All skeletons had previously been assessed for age and sex using standard non-metric osteological criteria (e.g., Buikstra and Ubelaker, 1994). Individuals were included in the sample if they were skeletally assessed as adults (Buikstra and Ubelaker, 1994) or the preserved third molars (loose or in-situ) were present as, at least, a developmentally complete crown.

The teeth were examined for carious lesions which were scored by size and location on the crown (occlusal, smooth surface [e.g., interdental, buccal, lingual], and/or the cemento-enamel junction [CEJ]). Lesions that involved adjacent teeth were attributed to both teeth. A carious lesion was recognized by a pit measuring at least $1 \mathrm{~mm}$ in diameter (Figure 2a) with evidence of demineralization at the orifice (Figure 2b, 2c) to distinguish it from pit-fissure irregularities on the occlusal and buccal surfaces. Assessment was aided by a $2 x-4 x$ hand lens. Carious lesions circa $4 \mathrm{~mm}$ in diameter were classified as medium and non-pulppenetrating lesions greater than $4 \mathrm{~mm}$ were classified as large. Pulp exposures were included based on the likelihood that they resulted from carious lesions from the crown or CEJ. Where preservation permitted, a necrotic tooth represented only by the roots or a pulp exposure associated with alveolar pocketing was not included (as periodontal disease could not be etiologically excluded). This exclusion did not seem to affect caries prevalence, as necrotic roots were isolated occurrences. Teeth exhibiting antemortem breakage were also excluded. These were identified by sharp-edged concavities with non-demineralized surfaces with evidence of masticatory use (i.e., polish or attrition) (Figure 2d, e, f).

Preservation ranged from fair to poor at all sites. Few individuals preserved complete enough maxillae or mandibles to reliably calculate dental caries 

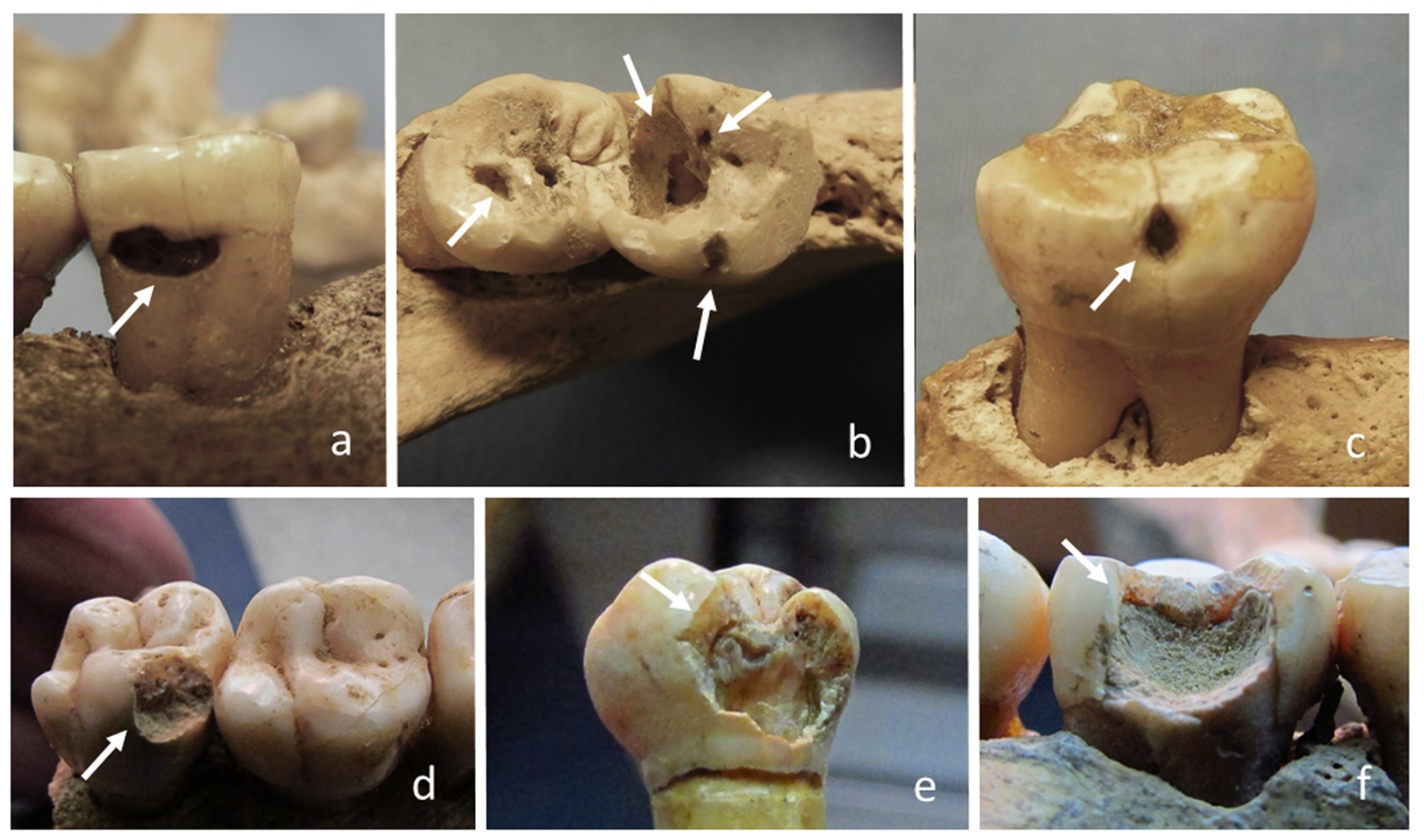

Figure 2. Examples of the extent of carious lesions from the Link (40HS6) sample. a) Burial 6 (Unit 19) exhibits a pulp-penetrating carie at the cemento-enamel junction, $b$ ) the first and second molars of Burial 3 (Unit 21) displaying (arrows) pulp exposure, pit-fissure occlusal cavities larger than $1 \mathrm{~mm}$, and a carious lesion in the buccal pit, c) and Burial 3 (Unit 67) illustrates a carious buccal pit. Non-carious antemortem cusp breakage (sharp perimeter, no demineralization) is exemplified in d) Burial 30 (Unit 21) with non-carious dentin-exposing breakage exhibited in e) Burial 32 (Unit 21) and f) Burial 38 (Unit 21).

prevalence by individual or to apply a Caries Correction Factor. The present study assesses dental caries by three tooth type categories irrespective of arch or antimere: incisors and canines (I/C), premolars (PM), and molars. Molars were also assessed by position in the tooth row (M1-M3). The samples were compared for sex differences within the site sample and between site samples. Adults were also segregated into three age-at-death categories: young (18 to $\sim 35$ years), middle ( 35 to 50 years), and mature (50+ years) based on the skeletal age-at-death range provided in the computer database.

A local comparative context was needed to assess whether the Middle Mississippian period Kentucky Lake samples were maize-intensive agriculturalists or whether they continued to cultivate native grasses. As no data sample is available (either published or available for research) from the Middle Cumberland Culture or the Mississippi River Valley of Tennessee, three unequivocal Late Mississippian ( 1300-1450 AD) period maize- intensive agriculturalist site samples from East Tennessee were utilized. The sites are also prereservoir archaeological salvage projects and are located along the Tennessee River or its tributary, the Little Tennessee River. The Little Tennessee River valley samples are from the sites of Toqua (40MR6) and Citico (40MR7) (i.e., Tellico Reservoir), and the Dallas (40HA1) site located along the Tennessee River (i.e., Chickamauga Reservoir) (Betsinger and Smith, 2013, 2018). The data were previously collected by the authors and reflect the same collecting protocols as the Kentucky Lake site samples. ${ }^{2}$

The prevalence rates of caries by the three tooth types were compared utilizing the Fisher's Exact Test ( $p$ 0.05). Intra-site comparisons were based on sex, while inter-site comparisons were made for the entire sample, for males, for females, and by age cohort. Further segregating the samples into age categories by sex yielded sample sizes too small for statistical assessment (e.g., $\mathrm{n}<10$ ). 


\section{Results}

Caries by tooth type

In the Link/Slayden total sample (Table 1), two percent of all preserved teeth exhibit at least one carious lesion. This is the lowest frequency of the three Kentucky Lake samples. When assessed by tooth class, Link/Slayden carious teeth are restricted to the posterior dentition. Over seven percent of all molars exhibit a carious lesion with the third molar the most frequently affected. However, this differential involvement is likely due to the paucity of first and second molars consequential to observed antemortem tooth loss. There are also no carious lesions in the incisiform dentition from the Late Woodland Hobbs site sample. The proportion of carious molar teeth is also circa seven percent. The percent of caries in the Hobbs premolar sample generates the only statistically significant difference between the two samples (Table 2) affect- ing the significant difference for all dentition $(\mathrm{p}=$ 0.0219). The Gray Farm sample has the highest frequency of any carious teeth (17.3\%) with caries present in all the tooth classes. Gray Farm has significantly higher caries prevalence for all but the third molar $(5 / 17,29.4 \%)$ compared to the Link/ Slayden sample $(5 / 33,15 \%)$. The relatively higher caries rates by tooth class in the Hobbs sample relative to Link/Slayden generate fewer statistically significant differences compared to the Gray Farm sample. Only the more frequent carious second molars in Gray Farm (33.3\% vs $4.8 \%$ ) are significantly different compared to Hobbs $(p=0.0448)$.

Sex differences in caries prevalence Given that females in many agriculturalist archaeological samples are likely more predisposed to dental caries (e.g., Lukacs, 1996, 2008; Lukacs and Largaespada, 2006), each site sample was tested for

Table 1. Caries presence, location, and severity by tooth type

\begin{tabular}{|c|c|c|c|c|c|c|c|c|c|c|c|}
\hline \multirow{3}{*}{$\begin{array}{l}\text { TOOTH } \\
\text { CLASS }\end{array}$} & \multicolumn{7}{|c|}{ LINK/SLAYDEN } & \multirow{2}{*}{\multicolumn{4}{|c|}{ caries severity }} \\
\hline & \multicolumn{2}{|c|}{ all adults } & \multicolumn{2}{|c|}{ males } & \multicolumn{2}{|c|}{ females } & caries location & & & & \\
\hline & \multicolumn{2}{|c|}{ cases $/ \mathrm{n} \quad \%$} & cases $/ \mathrm{n}$ & $\%$ & cases $/ \mathrm{n} \quad \%$ & $\%$ & occl / CEJ / $\mathrm{ss}^{2}$ & \multirow{2}{*}{$\mathrm{s}$} & $\mathrm{m} \mathrm{/}$ & \multicolumn{2}{|c|}{$1 / \mathrm{pex}^{3}$} \\
\hline $\mathrm{I} / \mathrm{C}_{1}$ & $0 / 121$ & 0 & $0 / 17$ & 0 & $0 / 74$ & 0 & $\begin{array}{lll}--- & --- & --- \\
\end{array}$ & & ---- & --- & --- \\
\hline PM & $0 / 98$ & 0 & $0 / 21$ & 0 & $0 / 55$ & 0 & --- & --- & --- & --- & --- \\
\hline M1 & $3 / 55$ & 5.5 & $0 / 6$ & 0 & $3 / 24$ & 12.5 & $0 / 3$ & $1 / 3$ & $1 / 3$ & $0 / 3$ & $1 / 3$ \\
\hline M2 & $2 / 48$ & 4.2 & $0 / 6$ & 0 & $1 / 15$ & 6.6 & $1 / 2 \quad 0 / 2$ & $0 / 2$ & $0 / 2$ & $0 / 2$ & $2 / 2$ \\
\hline M3 & $5 / 33$ & 15.1 & $1 / 2$ & --- & $2 / 11$ & 18.0 & $2 / 5 \quad 2 / 5 \quad 1 / 5$ & $2 / 5$ & $1 / 5$ & $0 / 5$ & $2 / 5$ \\
\hline ALL M & $10 / 138$ & 7.2 & $1 / 14$ & 7.1 & $6 / 50$ & 12.0 & $5 / 10 \quad 4 / 10 \quad 1 / 10$ & $3 / 10$ & $2 / 10$ & $2 / 10$ & $3 / 10$ \\
\hline ALL DENT & $10 / 493$ & 2.0 & $1 / 52$ & 1.9 & $6 / 179$ & 3.4 & $\begin{array}{lll}5 / 10 & 4 / 10 & 1 / 10\end{array}$ & $3 / 10$ & $2 / 10$ & $2 / 10$ & $3 / 10$ \\
\hline \multirow{3}{*}{$\begin{array}{l}\text { TOOTH } \\
\text { CLASS }\end{array}$} & \multicolumn{7}{|c|}{ HOBBS } & & & & \\
\hline & \multirow{2}{*}{\multicolumn{2}{|c|}{$\begin{array}{c}\text { all adults } \\
\text { cases } / \mathrm{n} \%\end{array}$}} & \multicolumn{2}{|c|}{ males } & \multicolumn{2}{|c|}{ female } & \multirow{2}{*}{$\begin{array}{l}\text { caries location } \\
\text { occl / CEJ / } \text { ss }^{2}\end{array}$} & \multicolumn{4}{|c|}{ caries severity } \\
\hline & & & cases $/ \mathrm{n}$ & $\%$ & cases $/ \mathrm{n}$ & $\%$ & & & $\mathrm{~m}$ & / 11 & $\mathrm{pex}^{3}$ \\
\hline $\mathrm{I}^{\mathrm{C}} \mathrm{C}_{1}$ & $0 / 38$ & 0 & $0 / 8$ & 0 & $0 / 22$ & 0 & $\begin{array}{lll}--- & --- & ---\end{array}$ & --- & --- & --- & --- \\
\hline PM & $3 / 30$ & 10.0 & $1 / 12$ & 8.0 & $2 / 16$ & 12.5 & $3 / 3$ & $3 / 3$ & $0 / 3$ & $0 / 3$ & $0 / 3$ \\
\hline M1 & $2 / 16$ & 12.5 & $2 / 4$ & ---- & $0 / 7$ & 0 & $1 / 2$ & $2 / 2$ & $0 / 2$ & $0 / 2$ & $0 / 2$ \\
\hline M2 & $1 / 21$ & 4.8 & $1 / 4$ & ---- & $0 / 15$ & 0 & $1 / 1^{4} \quad 0 / 1$ & $1 / 1$ & $0 / 1$ & $0 / 1$ & $0 / 1$ \\
\hline M3 & $1 / 17$ & 5.9 & $1 / 2$ & ---- & $0 / 6$ & 0 & $0 / 1$ & $1 / 1$ & $0 / 1$ & $0 / 1$ & $0 / 1$ \\
\hline ALL M & $4 / 54$ & 7.4 & $4 / 11$ & 7.1 & $0 / 28$ & 0 & $3 / 4$ & $4 / 4$ & $0 / 4$ & $0 / 4$ & $0 / 4$ \\
\hline ALL DENT & $7 / 110$ & 6.4 & $5 / 31$ & 16.1 & $2 / 66$ & 3.0 & $3 / 7$ & $7 / 7$ & $0 / 7$ & $0 / 7$ & $0 / 7$ \\
\hline TOOTH & \multicolumn{2}{|c|}{ all adults } & males & & \multicolumn{2}{|c|}{$\begin{array}{l}\text { GRAY FARM } \\
\text { females }\end{array}$} & caries location & \multicolumn{4}{|c|}{ caries severity } \\
\hline CLASS & cases/n & $\%$ & cases $/ \mathrm{n}$ & $\%$ & cases $/ \mathrm{n}$ & n $\%$ & occl / CEJ / $\mathrm{sS}^{2}$ & $\mathrm{~s}$ & $\mathrm{~m} /$ & / 1 / & pex \\
\hline $\mathrm{I} / \mathrm{C}_{1}$ & $4 / 48$ & 8.3 & $3 / 12$ & 25.0 & $1 / 21$ & 4.8 & $1 / 4 \quad 3 / 4$ & $3 / 4$ & $1 / 4$ & $0 / 4$ & $0 / 4$ \\
\hline PM & $4 / 58$ & 6.9 & $1 / 12$ & 8.0 & $1 / 22$ & 4.5 & $1 / 4$ & $3 / 4$ & $1 / 4$ & $0 / 4$ & $0 / 4$ \\
\hline M1 & $10 / 29$ & 34.0 & $2 / 10$ & 20.0 & $1 / 10$ & 10.0 & $3 / 10 \quad 3 / 10 \quad 4 / 10$ & $8 / 10$ & $2 / 10$ & $0 / 10$ & $0 / 10$ \\
\hline M2 & $7 / 21$ & 33.3 & $1 / 11$ & 9.0 & $4 / 9$ & 44.4 & $0 / 7 \quad 1 / 7$ & $7 / 7$ & $0 / 7$ & $0 / 7$ & $0 / 7$ \\
\hline M3 & $5 / 17$ & 29.4 & $0 / 4$ & 0 & $2 / 10$ & 20.0 & $0 / 5 \quad 1 / 5$ & $5 / 5$ & $0 / 5$ & $0 / 5$ & $0 / 5$ \\
\hline ALL M & $22 / 67$ & 3.3 & $3 / 25$ & 12.0 & $7 / 29$ & 24.1 & $14 / 22 \quad 3 / 22 \quad 6 / 22$ & $20 / 22$ & $2 / 22$ & $0 / 22$ & $0 / 22$ \\
\hline ALL DENT & $30 / 173$ & 17.3 & $7 / 49$ & 14.3 & $9 / 72$ & 12.5 & $15 / 30 \quad 5 / 30 \quad 7 / 30$ & $26 / 30$ & $4 / 30$ & $0 / 30$ & $\begin{array}{ll}0 & 0 / 30\end{array}$ \\
\hline
\end{tabular}

${ }^{1}$ Incisors and canines are pooled, ${ }^{2}$ smooth surface, ${ }^{3}$ pulp exposure, ${ }^{4}$ teeth with more than one carious lesion 
Table 2. Intra- and inter-Kentucky Lake sample caries prevalence by tooth type

\begin{tabular}{|c|c|c|c|}
\hline & Link/Slayden & Hobbs & Gray Farm \\
\hline \multicolumn{4}{|c|}{ sex differences within samples } \\
\hline $\mathrm{I} / \mathrm{C}$ & ---- & --- & 0.1250 \\
\hline PM & ---- & 1.0000 & 1.0000 \\
\hline M1 & --- & ---- & 1.0000 \\
\hline M2 & ---- & --- & ---- \\
\hline M3 & ---- & ---- & --- \\
\hline All M & 1.0000 & 0.0040 & 0.3095 \\
\hline \multirow[t]{2}{*}{ All Dent } & 1.0000 & 0.0091 & 0.7904 \\
\hline & Link/Slayden $\times$ Hobbs & Link/Slayden $x$ Gray Farm & Hobbs x Gray Farm \\
\hline \multicolumn{4}{|c|}{ caries in the total sample } \\
\hline $\mathrm{I} / \mathrm{C}$ & ---- & 0.0059 & 0.1264 \\
\hline PM & 0.0119 & 0.0179 & 0.6787 \\
\hline M1 & 0.3137 & 0.0009 & 0.1641 \\
\hline M2 & 1.0000 & 0.0025 & 0.0448 \\
\hline M3 & 0.6498 & 0.2768 & 0.1748 \\
\hline All M & 1.0000 & 0.0001 & 0.0007 \\
\hline All Dent & 0.0219 & 0.0001 & 0.0003 \\
\hline \multicolumn{4}{|c|}{ sample comparisons by males } \\
\hline $\mathrm{I} / \mathrm{C}$ & ---- & 0.0602 & 0.2421 \\
\hline PM & 0.3824 & 0.3824 & 1.0000 \\
\hline M1 & --- & ---- & ---- \\
\hline M2 & --- & -- & --- \\
\hline M3 & --- & --- & ---- \\
\hline All M & 0.1333 & 1.000 & 0.1665 \\
\hline All Dent & 0.0254 & 0.0281 & 1.0000 \\
\hline \multicolumn{4}{|c|}{ sample comparisons by females } \\
\hline $\mathrm{I} / \mathrm{C}$ & ---- & 0.2292 & 1.0000 \\
\hline PM & 0.0582 & 0.2857 & 0.5619 \\
\hline M1 & 1.0000 & 1.0000 & 1.0000 \\
\hline M2 & ---- & --- & --- \\
\hline M3 & ---- & 1.0000 & ---- \\
\hline All M & 0.0825 & 0.2110 & 0.0104 \\
\hline All Dent & 1.0000 & 0.0144 & 0.0577 \\
\hline
\end{tabular}

sex differences. There is an under-enumeration of males by molar type within both the Link/Slayden and Hobbs samples and for the M3 in the Gray Farm sample (see Table 1), therefore the between sex comparisons are restricted. There are no carious teeth in the I/C and PM categories in the Link/Slayden sample but the collective molar and collective dentition tests (including I/C and PM) are not significantly different by sex (see Table 2). In the tests by tooth type in the Gray Farm comparisons, males and females are not significantly different. The Hobbs sample exhibits a statistically different higher prevalence for males in the total tooth sample (16\% versus $3 \%)$, undoubtedly effected by the higher male prevalence in the (small) male collective molar sample $(36.4 \%$ versus $0 \%)$. In the absence of definitive differences between the sexes in caries prevalence, the samples can be pooled for statistical testing.

Caries prevalence compared to maize-intensive samples The total-sample comparisons of caries presence by tooth type of Link/Slayden with the Toqua, Citico, and Dallas samples generated statistically significant differences for all tests except the third molar (Table 3). In contrast, all the total sample compari- 
Table 3. Caries prevalence in the Kentucky Lake samples compared to maize-intensive samples

\begin{tabular}{|c|c|c|c|c|c|c|c|c|c|}
\hline & \multicolumn{3}{|c|}{ TOQUA } & \multicolumn{4}{|c|}{ CITICO } & \multicolumn{2}{|c|}{ DALLAS } \\
\hline & \multicolumn{2}{|c|}{ Total samples } & & \multicolumn{3}{|c|}{ Total samples } & \multicolumn{3}{|c|}{ Total samples } \\
\hline & $\begin{array}{c}\text { Link/ } \\
\text { Slayden }\end{array}$ & $\begin{array}{l}\text { Gray } \\
\text { Farm }\end{array}$ & Hobbs & $\begin{array}{c}\text { Link/ } \\
\text { Slayden }\end{array}$ & $\begin{array}{l}\text { Gray } \\
\text { Farm }\end{array}$ & Hobbs & $\begin{array}{l}\text { Link/ } \\
\text { Slayden }\end{array}$ & $\begin{array}{l}\text { Gray } \\
\text { Farm }\end{array}$ & Hobbs \\
\hline $\mathrm{I} / \mathrm{C}$ & 0.0001 & 1.0000 & 0.1070 & 0.0001 & 0.0649 & 1.0000 & 0.0034 & 0.5195 & 0.2444 \\
\hline PM & 0.0001 & 0.4999 & 1.0000 & 0.0001 & 0.4514 & 0.0575 & 0.0001 & 0.4816 & 1.0000 \\
\hline M1 & 0.0001 & 0.6742 & 0.1587 & 0.0005 & 0.3728 & 0.3784 & 0.0001 & 1.0000 & 0.1499 \\
\hline M2 & 0.0004 & 0.6059 & 0.0303 & 0.0003 & 0.0318 & 0.6086 & 0.0001 & 0.2352 & 0.0084 \\
\hline M3 & 0.1273 & 1.0000 & 0.0425 & 0.3657 & 0.1267 & 0.5691 & 0.1780 & 1.0000 & 0.0449 \\
\hline All M & 0.0001 & 0.4796 & 0.2811 & 0.0001 & 0.0015 & 0.2441 & 0.0001 & 0.7780 & 0.0001 \\
\hline All Dent & 0.0001 & 0.5131 & 0.0058 & 0.0001 & 0.0030 & 0.7503 & 0.0001 & 1.0000 & 0.0017 \\
\hline \multicolumn{4}{|c|}{ male samples } & \multicolumn{3}{|c|}{ male samples } & \multicolumn{3}{|c|}{ male samples } \\
\hline $\mathrm{I} / \mathrm{C}$ & 0.3833 & 0.1145 & ---- & 1.0000 & 1.0000 & --- & 0.6043 & 0.0425 & ---- \\
\hline PM & 0.0512 & 0.6982 & ---- & 0.2279 & 1.0000 & ---- & 0.1344 & 1.0000 & --- \\
\hline M1 & --- & 0.4930 & ---- & --- & 0.1947 & ---- & ---- & 0.2140 & ---- \\
\hline M2 & ---- & 0.2900 & --- & ---- & 1.0000 & --- & --- & 0.2757 & --- \\
\hline M3 & --- & ---- & --- & --- & --- & --- & ---- & --- & ---- \\
\hline All M & 0.1216 & 0.0995 & 0.5077 & 0.1980 & 0.4823 & 0.2163 & 0.0458 & 0.0938 & 0.7334 \\
\hline All Dent & 0.0089 & 0.8434 & 1.0000 & 0.0090 & 0.5987 & 0.8300 & 0.0033 & 1.0000 & 1.0000 \\
\hline \multicolumn{4}{|c|}{ female samples } & \multicolumn{3}{|c|}{ female samples } & \multicolumn{3}{|c|}{ female samples } \\
\hline $\mathrm{I} / \mathrm{C}$ & 0.0182 & 1.0000 & 0.3794 & 0.0004 & 0.1534 & 0.4900 & 0.0349 & 1.0000 & 0.6075 \\
\hline PM & 0.0319 & 1.0000 & 0.6307 & 0.0001 & 0.5374 & 0.0559 & 0.0020 & 0.4783 & 1.0000 \\
\hline M1 & 0.0782 & 0.7194 & ---- & 0.0526 & 0.0991 & ---- & 0.0160 & 0.0762 & ---- \\
\hline M2 & 0.1137 & --- & 0.0199 & 0.1903 & ---- & 0.2507 & 0.0034 & --- & 0.0006 \\
\hline M3 & 0.7201 & 0.7189 & --- & 1.0000 & 0.3330 & --- & 0.7089 & 0.7127 & ---- \\
\hline All M & 0.0017 & 0.6690 & 0.0002 & 0.0219 & 0.0004 & 0.8287 & 0.0045 & 0.1448 & 0.0001 \\
\hline All Dent & 0.0001 & 0.4142 & 0.0112 & 0.0001 & 0.0001 & 0.1247 & 0.0001 & 0.1925 & 0.0004 \\
\hline
\end{tabular}

sons by tooth type of the Gray Farm sample were not significantly different (Table 4). The Late Woodland Hobbs sample was significantly different in the posterior teeth from two (Dallas and Toqua) of the three East Tennessee Mississippian samples.

The number of statistical tests in the male cohort between the Kentucky Lake samples and the maize -intensive samples were restricted because of poor sample sizes in the male cohort. However, the congruence of the collective Gray Farm sample with the collective maize-intensive samples is maintained in the male sample comparisons (see Table 3). The under-enumeration of males in the Hobbs and Link/Slayden samples limits the number of teeth available to test. However, the pooled male dentitions in Link/Slayden are significantly different from the Toqua, Citico, and Dallas samples. The few tests available for the Hobbs sample are not significantly different for any of the maizeintensive samples. With larger samples available for the females, more tests are possible. Missing only a test for M2, there are otherwise no female sample differences between Gray Farm and any of the maize-intensive samples. The absence of caries in the incisiform teeth and premolars in the Link/ Slayden sample is significantly different from all the maize-intensive samples. The lower frequency of dental caries in the first molars of Link/Slayden is significantly different $(p=\leq 0.05)$ from the Citico 
Table 4. Comparison of site samples by caries location and severity

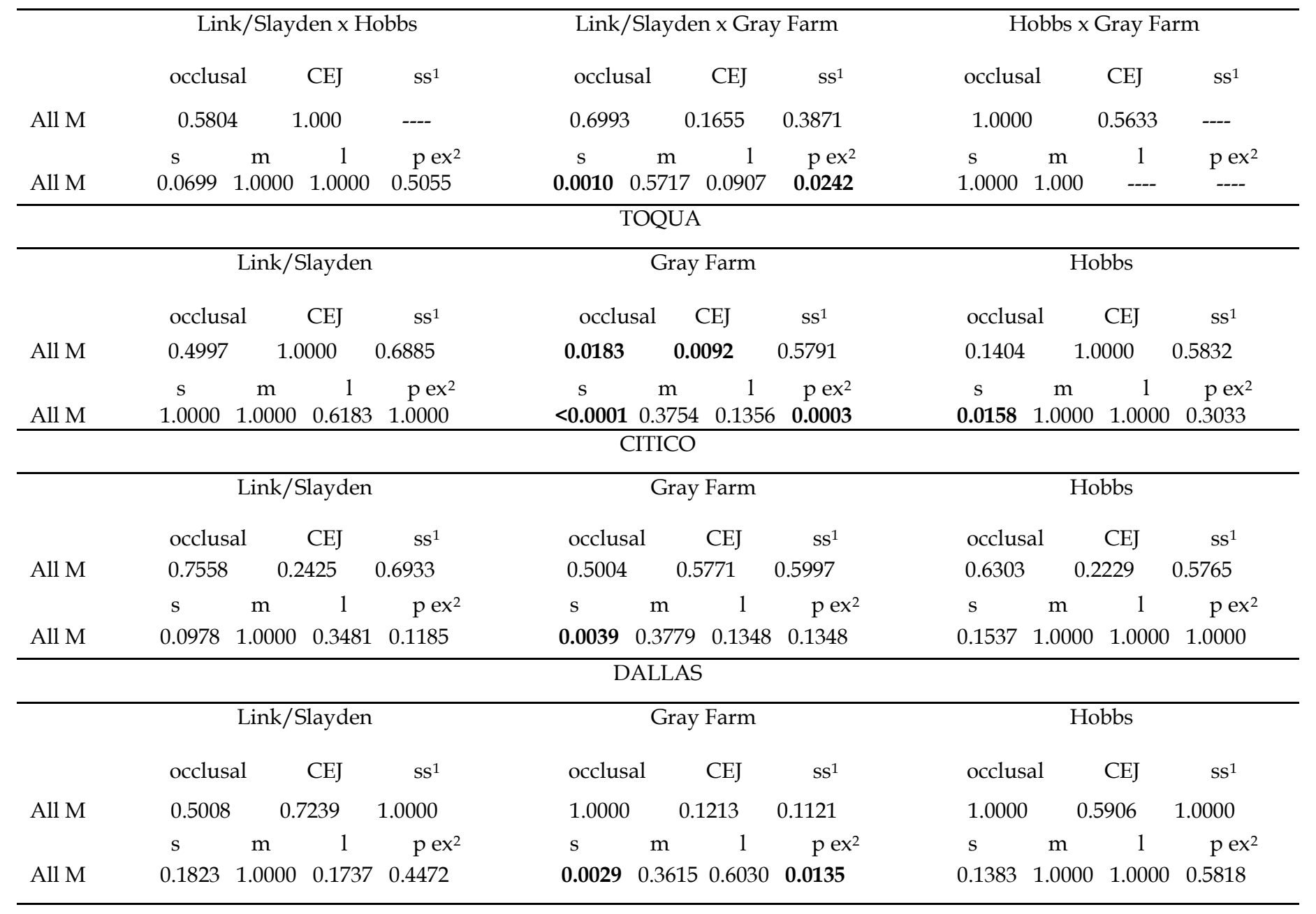

\footnotetext{
${ }^{1}$ smooth surface, ${ }^{2}$ pulp exposure
}

and Dallas samples, but not for the Toqua sample $(p=0.07194)$. The caries prevalence for females in the Link/Slayden samples for M2 and M3 are only significantly different for M2 in the Dallas sample. However, the pooled molar sample indicates that the fewer carious teeth in the Link/Slayden sample is significantly different from all of the maize intensive samples.

In general, the tests for Gray Farm reveal a similar pattern of caries prevalence compared to Toqua, Citico, and Dallas. In contrast, the Link/ Slayden sample is significantly different from the same samples. The Late Woodland Hobbs sample, collectedly and segregated by sex, exhibits caries prevalence congruence with the Citico sample.

Hobbs does have a lower case prevalence of caries in the posterior teeth when compared to the Toqua and Dallas samples.
Caries in Kentucky Lake by location and lesion size Inter-sample comparisons are limited to the posterior teeth as Link/Slayden and Hobbs have no carious I/C dentition (see Table 4). The most common locations for carious lesions are the occlusal surfaces followed by the CEJ. Smooth surface caries, that is, those that occur buccolingually and mesiodistally are infrequent and most often occur in a buccal pit (e.g., see Figure 2b, c). There is no statistically significant difference among the Kentucky Lake sites for crown/CEJ location of carious lesions. Lesion size in the four carious molars from the Hobbs sample are all small and there are no cases of pulp exposure. The larger samples of Link/Slayden and Gray Farm (see Table 4) generated statistically significant differences in the prevalence of small diameter caries and pulp exposures. The trend is toward larger size carious lesions in the Link/ 
Slayden sample and smaller size caries in Gray Farm.

Lesion size and location compared to maize-intensive samples

The comparisons for location of carious lesions on the tooth appear to not distinguish a maizeintensive diet in any patterned way. Locations for Link/Slayden and Hobbs do not differ from the Toqua, Citico, or Dallas samples (see Table 4). Gray Farm distinguishes from Toqua by having more occlusal relative to CEJ dental caries. Lesion size also does seem to discriminate the maize-intensive diet; neither Link/Slayden nor Hobbs differ from Citico or Dallas. The Hobbs sample differs in the proportion of small lesions from Toqua, but the prevalence difference in the expression of small lesions in Hobbs is likely an issue of sample size $(4 / 4,100 \%)$. The almost exclusive expression of dental caries as small lesions and the absence of pulp exposures (see Table 1) does distinguish Gray Farm from all three maize-intensive samples, as well as Link/Slayden.

Age-at-death differences in caries prevalence among Kentucky Lake samples

The paucity of burials classified as mature (50+ years of age) meant that age-at-death comparisons are restricted to the young ( $<35$ years) and middle age (35-50 years) cohorts. There are no carious teeth in the young adult samples of Hobbs $(0 / 21)$ and Link/Slayden (0/65). Whereas $12.5 \%$ of the dentition (9/72) in the Gray Farm sample are carious. The prevalence difference is statistically significant between Link/Slayden and Gray Farm (Table 5). All of the carious teeth identified for the Hobbs sample belonged to ageable adults and fall into the middle age-at-death category $(7 / 57$, $12.3 \%$ ). Only four carious teeth are ageable in the Link/Slayden sample and reflect 8.7 percent $(4 / 46)$ of the middle age cohort. Hobbs and Link/Slayden are not significantly different from each other $(p=0.7506)$. The larger proportion of carious teeth in the Gray Farm sample (6/31, 19.3\%) is not statistically different either from Link/Slayden or Hobbs (see Table 5).

Given that the preponderance of carious teeth are molars, the molar teeth are compared by age-at -death. In the young age-at-death category, the Link/Slayden absence of caries $(0 / 27)$ is significantly different from the Gray Farm sample $(7 / 37$, $18.9 \%)(p=0.0125)$ but the small sample of molars in the Hobbs sample (0/7) was not significantly different from Gray Farm or Link/Slayden (see Table 5). In the middle age-at-death category, Link/Slayden (4/21, $19 \%)$, Hobbs $(4 / 23,17.4 \%)$, and Gray Farm $(1 / 10,10 \%)$ are not significantly different from each other (See Table 5).

Table 5. Comparison of site samples by age at death

\begin{tabular}{lcccccc}
\hline & \multicolumn{2}{c}{ Link/Slayden $\times$ Hobbs } & \multicolumn{2}{c}{ Link/Slayden $\times$ Gray Farm } & \multicolumn{2}{c}{ Hobbs $\times$ Gray Farm } \\
& young & middle & young & middle & young & middle \\
All teeth & ---- & 0.7506 & $\mathbf{0 . 0 0 3 3}$ & 0.1891 & 0.2010 & 0.5304 \\
All molars & 1.0000 & 1.0000 & $\mathbf{0 . 0 1 2 5}$ & 1.0000 & 0.3126 & 1.0000
\end{tabular}

\begin{tabular}{lccccccc}
\hline & & \multicolumn{9}{c}{ TOQUA } & \multicolumn{2}{c}{ Hobbs } \\
& \multicolumn{2}{c}{ Link/Slayden } & \multicolumn{2}{c}{ Gray Farm } & \multicolumn{2}{c}{ young } & middle \\
& young & middle & young & middle & your & 0.3989 & 0.2221 \\
All Teeth & $\mathbf{0 . 0 0 9 6}$ & 0.0806 & 0.1830 & 1.0000 & 0.5988 & 0.1618
\end{tabular}

\begin{tabular}{lccccccc}
\hline & \multicolumn{9}{c}{ CITICO } \\
\hline & \multicolumn{2}{c}{ Link/Slayden } & \multicolumn{2}{c}{ Gray Farm } & \multicolumn{2}{c}{ Hobbs } \\
All teeth & young & middle & young & middle & & young & middle \\
All molars & $\mathbf{0 . 0 0 0 1}$ & 0.1582 & 0.8579 & 0.8078 & 0.0979 & 0.4638 \\
& $\mathbf{0 . 0 0 1 1}$ & 0.6095 & 0.8285 & 0.4614 & 0.2020 & 0.4610
\end{tabular}

\begin{tabular}{llcccccc}
\hline & & \multicolumn{2}{c}{ DALLAS } & \multicolumn{2}{c}{ Hobbs } \\
& \multicolumn{2}{c}{ Link/Slayden } & \multicolumn{2}{c}{ Gray Farm } & \multicolumn{2}{c}{ young } & middle \\
& young & middle & young & middle & $\mathbf{0 . 0 5 6 1}$ & 0.6827 \\
All teeth & $<\mathbf{0 . 0 0 0 1}$ & 0.2620 & 0.5971 & 0.6086 & 0.1073 & 0.5824 \\
All molars & $\mathbf{0 . 0 0 0 2}$ & 0.7757 & 0.3989 & 0.4433 & & 0.1073 \\
\hline
\end{tabular}


Age-at-death differences in caries prevalence compared to maize-intensive samples

Although Link/Slayden is a Middle Mississippian site sample, it has consistently statistically significant lower caries prevalence in the young age-atdeath category compared to Toqua, Citico, and Dallas. Antithetically, Gray Farm is statistically similar to all three. Hobbs does not differ from Toqua, but does for Dallas, and for Citico at a lower level of statistical reliability $(\mathrm{p}=\leq 0.10)$. All samples are similar in the middle age category (see Table 5).

Age-at-death difference for size and location of caries The preponderance of carious molars in the ageable Kentucky Lake sample $(n=17)$ are found on the occlusal surface (14/17). The absence of carious teeth in the young age-at-death category of Link/ Slayden and Hobbs means that no comparisons could be made among the Kentucky Lake samples. In the middle age-at-death category, there are nine molars in the collective sample. The molars in Hobbs and Link/Slayden have the same proportion of occlusal to cervical caries: three-to-one; the Gray Farm site has a single molar with an occlusal carious lesion. There is a subtle difference between the molars of Hobbs and Link/Slayden in the middle age-at-death category. All four of the lesions on the molars in the Hobbs sample are small in size while two of the occlusal carious lesions in the Link/Slayden sample are medium-sized. Link/ Slayden also exhibits the only ageable carious lesion (at the CEJ) with pulp exposure. The absence of a statistically valid sample in the Kentucky Lake samples negated comparisons with the maizeintensive samples.

\section{Discussion}

The archaeological context

The bioarchaeological co-association of the intensive cultivation of specific cariogenic carbohydrates with dental caries prevalence (i.e., number of carious teeth) greater than 10 percent is commonly reported world-wide (e.g., Caselitz, 1998; Karsten et al., 2015; Larsen, 1991, 2005; Lubell et al., 1994; Lukacs, 1992; Patterson, 1986; Šlaus et al., 2011; Temple and Larsen, 2007; Turner, 1979) as well as in the late prehistoric contiguous United States (e.g., Emerson et al., 2005; Larsen, 1981; Powell, 1985; Watson, 2005). The utility of dental caries to flag agricultural intensification and/or the cultivation of particular cariogenic carbohydrates is particularly critical in archaeological contexts where material culture is wanting. The Mississippian sites of the Kentucky Lake Reservoir are located in a cultural frontier between the Middle Cumberland Culture of the Nashville Basin and the various Mississippian period phases of the Mississippi River watershed located west of the West Tennessee Uplands (see Figure 1) (see Mainfort, 1996; Mainfort and Moore, 1998; Smith, 1990). The socioeconomic context of the Kentucky Lake Mississippian sites is poorly understood, as are the geographically adjacent late prehistoric cultures from the Mississippi River watershed of west Tennessee. The Mississippi River valley (MRV) archaeological contexts are frequently compromised by historic period development (e.g., cultivation, urbanization, transportation [railroad and highway construction]), major changes in the meander pattern of the Mississippi river, and, unfortunately, looting (Mainfort and Moore, 1998). To date, much of the late prehistoric MRV archaeological assessment centers on ceramic patterns and their geographic distributions. However, there is archaeobotanical evidence of maize at the Chucalissa site (40SY1) (AD 1250-1500) located in the south-western corner of the state of Tennessee near the present-day city of Memphis (Smith, 1990). The general paucity of bioarchaeological data in the Mississippi River Valley limits comparisons with the Kentucky Lake samples to all but the most well-known Middle-toLate Mississippian period site of Chucalissa (McNutt et al., 2012). Dental caries data for Chucalissa are restricted to the number of carious teeth $(271 / 1386,19.6 \%)$ (Robinson, 1976), which compares favorably $(p=0.7465)$ with the Gray Farm site sample $(30 / 173,17.3 \%)$, and contrasts with Link/Sladen $(\mathrm{p}=0.0001)$ and Hobbs $(\mathrm{p}=$ 0.0041).

Whether maize presence as a staple crop in the Mississippi River Valley influenced a diffusion toward, at least, Gray Farm, is problematic. There is scarce evidence of Mississippian occupation east of the Mississippi River floodplain in the West Tennessee Uplands (Mainfort, 1996; Smith, 1990) suggesting little or no cultural influence from the Mississippi River Valley. Indeed, according to the seminal archaeological overview of Mississippian sites in the Kentucky Lake Reservoir by Quentin Bass, Mississippianization was an in situ development rather than culture-bearing in-migration(s) of populations into the area (1985:93).

In contrast, the mortuary pattern of interment characterized by the lining of the grave pit with stone slabs ("stone box burials") associated with the Middle Cumberland Culture (AD 1250-1450, 
Thruston phase) of the Nashville Basin (Figure 1) (Dowd, 2008; Ferguson, 1972) frequently occurs in Kentucky Lake Reservoir Mississippian sites (Bass, 1985; Wamsley, 2018). Relative to the present study, the mortuary pattern of the Gray Farm site includes stone boxes as well as secondary interments of charnel house burials, whereas the entirety of the mortuary treatment at Link/Slayden is stone box (Bass, 1985; Wamsley, 2018). Predictably, no stone box interments occur at the Late Woodland Hobbs site (Kuemin Drews, 2000; Wamsley, 2018). Unfortunately, no caries data are available from Middle Cumberland Culture sites.

The socioeconomic circumstance of the Kentucky Lake samples is temporally important, as no Late Mississippian occupation (i.e., AD 1400-1600) is evident (Bass, 1985). This pre-Columbian abandonment of the lower Tennessee River valley is part of a larger post-AD 1450 regional depopulation phenomenon centered in the lower Ohio River valley known as "the Vacant Quarter" (Cobb and Butler, 2002; Williams, 1990). The abandonment is not well understood (Cobb and Butler, 2002; Williams, 1990), but may very well co-associate with precipitation corollaries of major climate change (i.e., "Little Ice Age," circa AD 1400-1850) (e.g., Anderson, 2001; Meeks and Anderson, 2013; Stinchcomb et al., 2011).

\section{The maize-intensive patterns}

The frequency of carious teeth by tooth type and caries prevalence segregated by age-at-death in the Gray Farm sample compared to the unequivocal maize-intensive samples from East Tennessee (e.g., Chapman, 2014; Polhemus, 1987) strongly suggests that it reflects a maize-intensive subsistence strategy. The strategic location of the Gray Farm site straddling the Cumberland and Tennessee River Valleys (see Figure 1) may have eco-culturally influenced the adoption of maize as a primary cultigen. That is, the Gray Farm site is located downstream from the communities of the Middle Cumberland Culture who are archaeologically identified as maize intensive (e.g., Beahm, 2013; Crites, 1984).

A singularity of the Gray Farm dental caries pattern occurs in lesion size and location relative to the Link/Slayden sample as well as the three Late Mississippian sites (Table 4). Gray Farm has an over enumeration of small carious lesions and an under-representation of pulp exposures. A number of variables could explain this finding. It could suggest a qualitatively different cariogenic food consumption pattern. That is, processing and/or consumption of maize that limits the metabolic activity of the oral bacteria. Or, more likely, a biased dental sample relative to antemortem tooth loss. The proportion of molar teeth out of the total tooth sample available for study is consistent across the age-at-death categories for Hobbs $(7 / 28$, $33 \%$ versus $23 / 57,40 \%)$ and Link/Slayden $(27 / 67$, $40.3 \%$ versus $19 / 44,43.2 \%$ ). However, in the young age-at-death category for Gray Farm, over 50 percent of the dental sample is composed of molars (37/71); in the middle age-at-death category, the proportion is reduced to a third (10/30). Given that neither Hobbs nor Link/Slayden register any carious lesions among the young adults, the retention of teeth with more advanced lesions in middle age is plausible. Whereas, cariogenesis initiated in (at least) early adulthood would inevitably progress to necrosis and tooth loss by middle age. A directed examination of antemortem tooth loss would corroborate this.

\section{The Link/Slayden patterns}

The archaeological context of the Link/Slayden site sample indicates a Mississippianized settlement pattern of a multiple-mound aggregated village (Bass, 1985), but it is clear that the subsistence pattern is different from Gray Farm and the East Tennessee Late Mississippian sites. The congruence of many of the dental caries comparisons with the Late Woodland Hobbs site and significant difference of the Link/Slayden sample with the maizeintensive samples affirms this. Interpretively important, the pattern and prevalence of dental caries is not consistent with pre-agricultural data. The total tooth sample caries prevalence for three Late Archaic hunter-gatherer samples from this reservoir is 2.7 percent $(93 / 3414)$ (Smith, 1982) and is significantly different from Hobbs $(p=0.0352)$ and Link/Slayden $(p=0.0316)$. The location of carious lesions on all teeth in the Archaic sample is almost exclusively at the CEJ $(53 / 58,91.4 \%)$, in contrast to Hobbs where half of all carious lesions are on the occlusal surface.

The congruence of Link/Slayden and Hobbs in caries prevalence as well as the similarity of certain caries frequencies of Hobbs with the maizeintensive samples is consistent with the history of plant domestication in the Kentucky Lake Reservoir area. That is, west-central Tennessee is part of the core area within which the Eastern Agricultural Complex developed that was well-established by the Late Woodland period (e.g., Smith, 2006, 2011; Smith and Yarnell, 2009). In particular, archaeobotanical data from sites upstream in the Duck River 
Valley (Normandy Reservoir) indicate there was a shift in the Late Woodland from the ceremonial use of maize to dietary use (Cobb and Faulkner, 1978; Shea, 1977). However, an elevation in caries prevalence does not necessarily indicate a shifting reliance toward maize as high prevalence has been observed in Woodland contexts pre-dating the introduction of maize (e.g., Alfono-Durrity et al., 2014; Rose and Marks, 1985; Rose et al., 1991).

Although the location of Link/Slayden may be geographically remote relative to the core area of the maize-intensive MCC, it is more likely that the site sample is temporally earlier than Gray Farm. A recent assessment of the ceramics at the Slayden site suggests a primary occupation at the earlier end of the temporal spectrum ( AD 1100-1200) (Lunn, 2013), implying that maize-intensive agriculture, and perhaps the primary occupation of Gray Farm, post-dated circa AD 1200 in the Kentucky Lake Reservoir area.

Dental caries as an archaeological problem-solving tool. The progressive nature of carious lesions ultimately results in tooth necrosis and exfoliation. The geometry and length of time particular teeth are in occlusion certainly affect pathogenesis and vulnerability. However, the process is not simply linear as many intrinsic (e.g., general health, hypoplastic defects, attrition, periodontal disease, pregnancy/ lactation) and extrinsic (e.g., food processing, food preparation) factors are involved. In short, dental caries is not simply a proxy for the dietary reliance of one or another fermentable carbohydrate. However, as the Kentucky Lake samples illustrate, the complexities of cariogenesis can be modulated to address particular archaeological questions despite the analytical constraints imposed by poor preservation and small sample size. The results of the present study suggest that maize-intensive agriculture temporally occurred in the Middle Mississippian period ( AD 1100-1350) of the Kentucky Lake Reservoir area of west-central Tennessee postdating the primary occupation of the Link/Sladen sites ( AD 1200). All Mississippian period occupation of west-central Tennessee terminated by $\sim \mathrm{AD}$ 1450.

\section{Endnotes}

1 The research protocols of the osteoarchaeological samples currently curated by the Frank $\mathrm{H}$.

McClung Museum, inclusive of the samples in this study, are not eligible for any form of destructive analysis.

2 In accordance with NAGPRA regulations, the osteoarchaeological samples currently curated by the Frank H. McClung Museum are no longer eligible for research purposes pending repatriation and reburial.

\section{Acknowledgements}

The authors would like to thank the staff of the Frank H. McClung Museum for our long-standing access to the collections. In particular, we would like to thank Dr. Jefferson Chapman (Museum Director, retired) and Dr. Lynne P. Sullivan (Curator of Collections, retired).

\section{REFERENCES}

Alfonso-Durruty, M.P., Bauder, J., and Giles, B. (2014). Dental pathologies and diet in the Middle Woodland burials from Helena Crossing, Arkansas. North American Archaeologist, 35(1), 87-108.

Anderson, D.G. (2001). Climate and culture change in prehistoric and early historic eastern North America. Archaeology of Eastern North America, 29, 143-186.

Armelagos, G.J. (2003). Bioarchaeology as anthropology. Archeological Papers of the American Anthropological Association, 13(1), 27-40.

Beahm, E.L. (2013). Mississippian polities in the Middle Cumberland region of Tennessee. (PhD Thesis). University of Georgia, Athens, GA.

Bass, Q.R., II. (1985). Sociopolitical and economic aspects of the Mississippian occupation in the Lower Tennessee River Valley. Manuscript on file, Department of Sociology and Anthropology, Middle Tennessee State University, Murfreesboro.

Beck Jr., R.A. (2003). Consolidation and hierarchy: Chiefdom variability in the Mississippian Southeast. American Antiquity, 68(4), 641-661.

Bense, J.A. (2016). Archaeology of the Southeastern United States: Paleoindian to World War I. New York, NY: Routledge.

Brehm, H.C. (1981). History of the Duck River Cache. Miscellaneous Paper No. 6, Tennessee Anthropological Association, Knoxville.

Betsinger, T.K., \& Smith, M.O. (2013). Caries prevalence and the late prehistoric Dallas phase: A regional cultural pattern of female maize consumption in late prehistoric East Tennessee. American Journal of Physical Anthropology, S150, 80.

Betsinger, T.K., \& Smith, M.O. (2018). Regional differences in caries by sex and social status in late prehistoric East Tennessee. In S.C. Hodge, K. Schuler (Eds.), Bioarchaeology of the American 
Southeast: Approaches to bridging health and identity in the past (pp. 54-68). Tuscaloosa: University of Alabama Press.

Buikstra, J.E., Autry, W., Breitburg, E., Eisenberg, L., \& van der Merwe, N. (1988). Diet and Health in the Nashville Basin: Human Adaptation and Maize Agriculture in Middle Tennessee. In B.V. Kennedy \& G.M. Le Moine (Eds.), Diet and Subsistence: Current Archaeological Perspectives (pp. 243-259). Proceedings of the Nineteenth Annual Conference of the Archaeological Association of the University of Calgary.

Buikstra, J.E., \& Beck, L.A. (Eds.). (2017). Bioarchaeology: The contextual analysis of human remains. New York, NY: Routledge.

Buikstra, J.E., \& Ubelaker, D.H. (1994). Standards for data collection from human skeletal remains. Arkansas Archaeological Survey Research Series.

Caselitz, P. (1998). Caries: Ancient plague of humankind. In K.W. Alt, F.W. Rösing, \& M. Teschler-Nicola (Eds.), Dental Anthropology (pp. 203-226). Vienna: Springer.

Chapman, J. (2014). Tellico archaeology: 12,000 years of Native American history. University of Tennessee Press.

Cobb, C.R. (2003). Mississippian chiefdoms: How complex? Annual Review of Anthropology, 32, 63 -84. https://doi.org/10.1146/ annurev.anthro.32.061002.093244

Cobb, C.R., \& Butler, B.M. (1992). The vacant quarter revisited: Late Mississippian abandonment of the lower Ohio Valley. American Antiquity, 67(4), 625-641. https:// doi.org/10.2307/1593795

Cobb, J. E., \& Faulkner, C. H. (1978). The Owl Hollow Project: Middle Woodland Settlement and Subsistence Patterns in the Eastern Highland Rim of Tennessee. Ms. on file, National Science Foundation, Washington, DC.

Crites, G.D. (1984). Late Mississippian Paleoethnobotany in the Nashville Basin: The Evidence from Averbuch. In W.E. Klippel, W.B. Bass (Eds.), Averbuch: A Late Mississippian Manifestation in the Nashville Basin (pp. 12.11-12.23). Department of Anthropology, University of Tennessee, Knoxville. Submitted to the National Park Service, Atlanta.

Dalan, R.A. (1997). The construction of Mississippian Cahokia. In T.R. Pauketat, \& T.E. Emerson (Eds.), Cahokia: Domination and Ideology in the Mississippian World (pp. 89 -102). Lincoln: University of Nebraska Press.

Dowd, J.T. (2008). The Cumberland stone-box buri- als of middle Tennessee. Tennessee Archaeolo$g y, 3(2), 163-180$.

Dye, D.H. (2002). The 1936 University of Tennessee WPA-TVA Excavations at the Link Farm Site (40HS6), Humphreys County, Tennessee. Paper presented at the Annual Meeting of the Southeastern Archaeological Conference, Biloxi. Dye, D. H. (2003). The Link Farm Site (40HS6) in Regional Perspective. Paper presented at the Annual Meeting of Current Research in Tennessee Archaeology (CRITA), Nashville.

Dye, D.H. (2007). The Duck River Cache and the Evolution of Mississippian Symbolic Weaponry. Paper presented at the Annual Meeting of the Current Research in Tennessee Archaeology Meetings, Lebanon, TN.

Emerson, T.E., Hedman, K.M., \& Simon, M.L. (2005). Marginal horticulturalists or maize agriculturalists? Archaeobotanical, paleopathological, and isotopic evidence relating to Langford Tradition maize consumption. Midcontinental Journal of Archaeology, 30(1), 67-118. https://doi.org/10.1179/mca.2005.003

Ferguson, R.B. (Ed.) (1972). The Middle Cumberland Culture. Vanderbilt University Publications in Anthropology, No 3, Nashville.

Fritz, G. (1990). Multiple pathways to farming in precontact Eastern North America. Journal of World Prehistory, 4,387-435.

Fritz, G. (1992). "Newer," "better" maize and the Mississippian emergence: A critique of prime mover explanations. In W.I. Woods (Ed.), Late Prehistoric Agriculture: Observations from the Midwest (pp. 19-43). Springfield: Illinois Historic Preservation Agency.

Hatch, J.W. (1987). Mortuary indicators of organizational variability among late prehistoric chiefdoms in the Southeastern U.S. interior. In R.D. Drennan, \& C.A. Uribe (Eds.). Chiefdoms in the Americas (pp. 9-18). Lanham, Maryland: University Press of America.

Hutchinson, D.L., Larsen, C.S., Schoeninger, M.J., \& Norr, L. (1998). Regional variation in the pattern of maize adoption and use in Florida and Georgia. American Antiquity, 63(3), 397-416.

Jolley, R.L. (1983). Mississippian adaptations to the Middle Cumberland drainage of Central Tennessee. Midcontinental Journal of Archaeology, 8 (1), 83-90. https://www.jstor.org/ stable/20707901

Karsten, J.K., Heins, S.E., Madden, G.D. \& Sokhatskyi, M.P. (2015). Dental health and the transition to agriculture in prehistoric Ukraine: a study of dental caries. European Journal of Ar- 
chaeology, 18(4), 562-579. https://

doi.org/10.1179/1461957115Y.0000000004.

Kidder, T.R. (2004). Plazas as architecture: An example from the Raffman Site, Northeast Louisiana. American Antiquity, 69(3), 514-532. https:// doi.org/10.2307/4128404.

King, A. (2001). Long-term histories of Mississippian centers: The developmental sequence of Etowah and its comparison to Moundville and Cahokia. Southeastern Archaeology, 20, 1-17.

King, A. (2017). Mississippian Period: Overview. New Georgia Encyclopedia. 08 June 2017. Web. 28 April 2019.

Knight, Jr., V.J. (2006). Farewell to the southeastern ceremonial complex. Southeastern Archaeology, 25(1), 1-5.

Knight Jr., V.J., Brown, J.A., \& Lankford, G.E. (2001). On the subject matter of Southeastern Ceremonial Complex art. Southeastern Archaeology, 20(2), 129-141.

Kuemin Drews, N. (2000). A bioarchaeological perspective of Mississippian period warfare in westcentral Tennessee. (MA thesis). Northern Illinois University, DeKalb, IL.

Larsen, C.S. (1981). Skeletal and dental adaptations to the shift to agriculture on the Georgia coast. Current Anthropology, 22(4), 422-423. https://doi.org/10.1086/202697

Larsen, C.S., Shavit, R., \& Griffin, M.C. (1991). Dental caries evidence for dietary change: An archaeological context. In M.A. Kelley \& C.S. Larsen (Eds.). Advances in Dental Anthropology (pp. 179-202). New York: John Wiley \& Sons.

Larsen, C.S. (2015). Bioarchaeology: interpreting behavior from the human skeleton, second edition. Cambridge: Cambridge University Press.

Lewis, R.B, Stout, C., \& Wesson, C.B. (1998). The design of Mississippian towns. In R.B. Lewis, \& C. Stout, (Eds.). Mississippian Towns and Sacred Spaces (pp. 1 -21). Tuscaloosa: University of Alabama Press.

Lubell, D., Jackes, M., Schwarcz, H., Knyf, M., \& Meiklejohn, C., (1994). The Mesolithic-

Neolithic transition in Portugal: Isotopic and dental evidence of diet. Journal of Archaeological Science, 21(2), 201-216. https:/ /

doi.org/10.1006/jasc.1994.1022

Lukacs, J.R. (1992). Dental paleopathology and agricultural intensification in South Asia: New evidence from Bronze Age Harappa. American Journal of Physical Anthropology, 87(2), 133-150. https://doi.org/10.1002/ajpa.1330870202

Lukacs, J.R. (1996). Sex differences in dental caries rates with the origin of agriculture in South
Asia. Current Anthropology, 37(1), 147-153.

https://doi.org/10.1086/204481

Lukacs, J.R. (2008). Fertility and agriculture accentuate sex differences in dental caries rates. Current Anthropology, 49(5), 901-914. https://doi.org/10.1086/592111

Lukacs, J.R., \& Largaespada, L.L. (2006). Explaining sex differences in dental caries prevalence: Saliva, hormones, and "life-history" etiologies. American Journal of Human Biology, 4, 540555. https://doi.org/10.1002/ajhb.20530

Lunn, A.R. (2013). WPA archaeology at the Slayden site, Humphreys County, Tennessee. In J.L. Cordell, J.F. Doershuk, D.H. Dye, S.W. Hammerstedt, J.R. Johnson, K. Kiernan, G.D. Lattanzi (Eds.) Shovel Ready: Archaeology and Roosevelt's New Deal for America (pp. 147-164). Tuscaloosa: University of Alabama Press.

Mainfort Jr., R.C. (1996). Late period chronology in the Central Mississippi Valley: A Western Tennessee perspective. Southeastern Archaeology, 15 (2), 172-181.

Mainfort, R.C. \& Moore, M.C. (1998). Graves Lake: A Late Mississippian Period village in Lauderdale County, Tennessee. IN M.J. O'Brien \& R.C. Dunnell (Eds.) Changing Perspectives on the Archaeology of the Central Mississippi Valley (pp 99-123). Tuscaloosa: University of Alabama Press.

Martin, D.L., Harrod, R.P., \& Pérez, V.R. (2013). Bioarchaeology: An integrated approach to working with human remains. New York, NY: Springer Press.

McNutt, C.H., Franklin, J.D., \& Henry, E.R. (2012). New perspectives on Mississippian occupations in western Tennessee and northwestern Mississippi: Recent chronological and geophysical investigations at Chucalissa (40SY1), Shelby County, Tennessee. Southeastern Archaeology, 31(2), 231-250. https://doi.org/10.1179/ sea.2012.31.2.007

Meeks, S.C., \& D.G. Anderson (2013). Drought, Subsistence Stress, and Population Dynamics: Assessing Mississippian Abandonment of the Vacant Quarter. In J.D. Wingard, S.E. Hayes Soils (Eds.), Climate, \& Society: Archaeological Investigations in Ancient America (pp. 61-83). University Press of Colorado, Boulder.

Moore, M.C., Breitburg, E., Smith, K.E., \& Trubitt, M.B. (2006). One hundred years of archaeology at Gordontown: A fortified Mississippian town in middle Tennessee. Southeastern Archaeology, 25(1), 89-109.

Muller, J. (1989). The southern cult. In P. Galloway, 
(Ed.). The Southeastern Ceremonial Complex, Artifacts and Analysis: The Cottonlandia Conference (pp. 11-26). Lincoln: University of Nebraska Press.

Patterson, D.K. (1986). Changes in oral health among prehistoric Ontario populations. Canadian Review of Physical Anthropology, 5(2), 3-13.

Pauketat, T.R. (1994). The ascent of chiefs: Cahokia and Mississippian politics in native North America. Tuscaloosa: University of Alabama Press.

Pauketat, T.R. (2007). Chiefdoms and other archaeological delusions. New York: Altamira Press.

Polhemus, R. R. (1987). The Toqua Site40MR6. Department of Anthropology, University of Tennessee, Report of Investigations, 41.

Powell, M.L. (1985). The analysis of dental wear and caries for dietary reconstruction. In R.I. Gilbert, \& J.H. Mielke, (Eds.), The Analysis of Prehistoric Diets (pp. 307-338). New York: Academic Press.

Reilly, F.K., \& Garber, J. (Eds.). (2007). Ancient objects and sacred realms. Austin: University of Texas Press.

Robinson, R.K. (1976). Social status, stature, and pathology at Chucalissa (40SY1), Shelby County, Tennessee. (MA Thesis). University of Tennessee, Knoxville, TN.

Rose, J.C. \& Marks, M.K. (1985). 1985 Bioarchaeology of the Alexander Site, In E.T. Hemmings, J.H. Hoise (Eds.) The Alexander Site (pp. 75-98), Arkansas Archaeological Survey Research Report No. 24, Fayetteville, Arkansas.

Rose, J.C., Marks, M.K., \& Tieszen, L.L. (1991). Bioarchaeology and Subsistence in the Central and Lower Portions of the Mississippi Valley, In M.L. Powell, P. Bridges, \& A.M. Wagner Mires (Eds.), What Mean These Bones? (pp. 721). The University of Alabama Press, Tuscaloosa.

Scarry, C. M. (1993). Variability in Mississippian crop production strategies. In C.M. Scarry (Ed.), Foraging and Farming in the Eastern Woodlands (pp. 78-90). Gainesville: University Press of Florida.

Scarry, C.M. (2008). Crop husbandry practices in North America's eastern woodlands. In E. Reitz, C.M. Scarry, \& S.J. Scudder, (Eds.), Case Studies in Environmental Archaeology (pp. 391404). New York: Springer.

Shea, A. B. (1977). Comparison of Middle Woodland and Early Mississippian subsistence patterns: analysis of plant remains from an archaeological site in the Duck River Valley, Tennessee, supple- mented by the potentially exploitable native flo$\mathrm{ra}$ (Doctoral dissertation, University of Tennessee, Knoxville).

Simon, M.L. (2017). Reevaluating the evidence for Middle Woodland maize from the Holding Site. American Antiquity, 82(1), 140-150. https://doi.org/10.1017/aaq.2016.2

Šlaus, M., Bedić, Ž., Rajić Šikanjić, P., Vodanović, M., \& Domić Kunić, A. (2011). Dental health at the transition from the Late Antique to the early medieval period on Croatia's eastern Adriatic coast. International Journal of Osteoarchaeology, 21(5), 577-590. https:/ / doi.org/10.1002/ oa.1163

Smith, B.E. (Ed.). (1990). The Mississippian emergence. Washington, D.C.: Smithsonian Institution Press.

Smith, B.E. (2006). Eastern North America as an independent center of plant domestication. Proceedings of the National Academy of Sciences 103(33), 12223-12228. https:/ / doi.org/10.1073/pnas.0604335103

Smith, B.E. (2011). The cultural context of plant domestication in Eastern North America. Current Anthropology, 52(Suppl 4), S471-S484 doi: 10.1086/659645

Smith, B.E. (2017). Tracing the initial diffusion of maize in North America. In N. Bolvin, R. Crassard, M. Petraglia, (Eds.), From Colonization to Globalization: Species Movements in Human History (pp. 332-348). Cambridge: Cambridge University Press.

Smith, B.E., \& Yarnell, R.A. (2009). Initial formation of an indigenous crop complex in eastern North America at 3800 B.P. Proceedings of the National Academy of Sciences, 106(16), 65616566. https://doi.org/10.1073/ pnas.0901846106.

Smith, G.P. The Walls phase and its neighbors. In D. Dye and C. Cox, (Eds.), Towns and Temples Along the Mississippi (pp. 135-169). Tuscaloosa: University of Alabama Press.

Smith, K.E. (1992). The Middle Cumberland Region: Mississippian Archaeology in North Central Tennessee. (PhD. Dissertation). Nashville: Vanderbilt University.

Stinchcomb, G. E., Messner, T. C., Driese, S. G., Nordt, L. C., \& Stewart, R. M. (2011). Precolonial (AD 1100-1600) sedimentation related to prehistoric maize agriculture and climate change in eastern North America. Geology, 39 (4), 363-366.

Stojanowski, C.M., \& Duncan, W.N. (2015). Engaging bodies in the public imagination: Bioar- 
chaeology as social science, science, and humanities. American Journal of Human Biology, 27 (1), 51-60. https://doi.org/10.1002/ajhb.22522

Temple, D.H., \& Larsen, C.S. (2007). Dental caries prevalence as evidence for agriculture and subsistence variation during the Yayoi period in prehistoric Japan: Biocultural interpretations of an economy in transition. American Journal of Physical Anthropology, 134(4), 501-512. https:/ / doi.org/10.1002/ajpa.20694.

Turner, C.G. (1979). Dental anthropological indications of agriculture among the Jomon people of central Japan. X. Peopling of the Pacif-

ic. American Journal of Physical Anthropology, 51 (4), 619-635. https://doi.org/10.1002/ ajpa.1330510413.

VanDerwarker, A.M., Bardolph, D.N., \& Scarry, C.M. (2017). Maize and Mississippian beginnings. In G.D. Wilson, (Ed.), Mississippian Beginnings (pp.29-70). Gainesville: University Press of Florida.

Wamsley, B.A. (2018). Mortuary patterns in westcentral Tennessee: Contextualizing historic field data from nine Mississippian period sites. (MA Thesis). Illinois State University, Normal, IL.

Watson, J.T. (2005). Cavities on the cob: dental health and the agricultural transition in Sonora, Mexico. (PhD Dissertation). University of Nevada, Las Vegas.

Williams, S. (1990). The vacant quarter and other late events in the Lower Valley. In D.H. Dye, \& C.A. Cox, (Eds.), Towns and Temples Along the Mississipppi (pp. 170-180). Tuscaloosa: University of Alabama Press.

Wilson, G. D. (2017). Mississippian beginnings. Gainesville: University Press of Florida. 